\title{
Elevated levels of dehydroepiandrosterone as a potential mechanism of dendritic cell impairment during pregnancy
}

\author{
Elena R Chernykh', Olga Yu Leplina1*, Marina A Tikhonova', Nataliya V Seledtsova', Tamara V Tyrinova',
} Nataliya A Khonina', Alexandr A Ostanin ${ }^{1}$ and Nataliya M Pasman²

\begin{abstract}
Background: This study aimed to test the hypothesis that immune dysfunction and the increased risk of spontaneous abortion in pregnant women with hyperandrogenia (HA) are caused by the reduced tolerogenic potential of dendritic cells (DCs) that results from elevated levels of dehydroepiandrosterone sulfate (DHEAS).

Methods: The phenotypic and functional properties of monocyte-derived DCs generated from blood monocytes from non-pregnant women, women with a normal pregnancy, or pregnant women with $\mathrm{HA}$, as well as the in vitro effects of DHEAS on DCs in healthy pregnant women were investigated.

Results: In a normal pregnancy, DCs were shown to be immature and are characterized by a reduced number of $\mathrm{CD}_{3} 3^{+}$and $\mathrm{CD} 25^{+} \mathrm{DCs}$, the ability to stimulate type $2 \mathrm{~T}$ cell responses and to induce $\mathrm{T}$ cell apoptosis. By contrast, DCs from pregnant women with HA had a mature phenotype, were able to stimulate both type 1 (IFN- $\gamma$ ) and type 2 (IL-4) T cell responses, and were characterized by lower B7-H1 expression and cytotoxic activity against CD $8^{+}$ T cells. The addition of DHEAS to cultures of DCs from healthy pregnant women induced the maturation of DCs and increased their ability to activate type $1 \mathrm{~T}$ cell responses.
\end{abstract}

Conclusion: Our data demonstrated the reduction in the tolerogenic potential of DCs from pregnant women with HA, and revealed new mechanisms involved in the hormonal regulation of DCs mediated by DHEAS.

Keywords: Dendritic cells, Dehydroepiandrosterone sulfate (DHEAS), Pregnancy, Tolerogenic activity

\section{Background}

The hypothesis that tolerance plays a major role in pregnancy was first proposed by P. B. Medawar more than 50 years ago [1]. Subsequent studies not only confirmed the assumptions of Medawar, but also resulted in significant progress towards understanding the phenomenon of immunological tolerance. It has become evident that despite the anatomical separation of the mother and fetus, the induction of tolerance requires the recognition of fetal antigens by maternal immune cells [2]. Tolerance induction involves several mechanisms, including immunological ignorance [3], $\mathrm{T}$ cell apoptosis and anergy [4,5], and immunosuppression mediated by both regulatory cells

\footnotetext{
* Correspondence: oleplina@mail.ru

'Laboratory of Cellular Immunotherapy, Research Institute of Fundamental and Clinical Immunology, 14, Yadrintsevskaya St., 630099 Novosibirsk, Russia Full list of author information is available at the end of the article
}

$[6,7]$ and cytokines $[8,9]$. Furthermore, a key role for dendritic cells (DCs) in immune tolerance that occurs during pregnancy has been proposed.

DCs are best known as cells that can induce an adaptive immune response [10,11], although DCs were also recently shown to be capable of suppressing immune responses [12]. Initially, this tolerogenic activity was thought to be associated with an immature state of DCs or with the plasmacytoid DC subset [12,13]. However, subsequent studies showed that intermediate and mature DCs can also exhibit tolerogenic properties $[14,15]$, and DC phenotypes can be influenced by various anti-inflammatory and immunosuppressive mediators [16-18]. DCs can acquire tolerogenic features upon exposure to prostaglandin $E_{2}$, vitamin $\mathrm{D}_{3}$, HLA-G molecules, IL-21, IL-16, IL-4, thrombopoietin, M-CSF, G-CSF, HGF, VIP (vasoactive intestinal peptide), or TSLP (thymic stromal lymphopoietin), which 
are present in large amounts in the decidua $[3,12,19,20]$. Additionally, many apoptotic trophoblast cells enter the circulation during pregnancy, and their engulfment might also induce tolerogenic activity in DCs [21].

The functional activity of DCs has been shown to be controlled by hormones, including glucocorticoids and sex hormones, such as chorionic gonadotropin, estrogens, and progesterone, which can increase the tolerogenic potential of DCs [22-27]. Therefore, it was suggested that hormones can modulate DCs and that the microenvironment represents a key factor that can trigger and regulate immunological tolerance [28]. Accordingly, dysfunction in hormone secretion pathways can significantly affect the tolerogenic potential of DCs.

Previously, we showed that pregnant women with elevated levels of DHEAS, which results from minor forms of adrenal hyperandrogenia (HA), exhibit immune abnormalities. In particular, they show a reduced number of $\mathrm{CD} 44^{+} \mathrm{CD} 25^{+}$regulatory $\mathrm{T}$ cells and an increased number of activated NK cells compared to women with a normal pregnancy [29]. Because similar immune abnormalities have been described in women with recurrent miscarriages [30,31], we suggested that immune dysfunction might be the cause of the increased abortion rate in pregnant women with elevated levels of DHEAS [32,33]. The stimulatory effect of DHEAS on the immune system that results in the activation of natural killer cells (NK cells) and Th1 cells is well-known [34]. We have also shown that DHEAS can induce the in vitro maturation and Th1-stimulating activity of DCs [35]. Therefore, we suggest that immune dysfunctions in pregnant women with increased levels of DHEAS could result from impaired immunological tolerance, and the reduction in the tolerogenic potential of DCs might be caused by elevated concentrations of DHEAS.

To test this hypothesis, we studied the phenotypic and functional properties of monocyte-derived DCs in nonpregnant women, women with a normal pregnancy, and pregnant women with elevated levels of DHEAS. We also assessed in vitro the effect of DHEAS on DCs in healthy pregnant women.

\section{Methods}

\section{Patients}

This study included three groups of women (Table 1). The control group included 42 fertile non-pregnant women (who had at least one successful pregnancy and no previous abortions) whose menstrual cycles were regular (mean age $30.2 \pm 0.2$ years). All women in the control group had normal serum levels of DHEAS. Study group I included 66 healthy pregnant women who did not have any infectious or endocrine diseases, or clinical signs of hyperandrogenism, and who exhibited normal serum levels of DHEAS $(<1.8 \mathrm{mg} / \mathrm{ml})$. Study group II included 44 pregnant women
Table 1 Characteristics of groups of patients

\begin{tabular}{|c|c|c|c|}
\hline \multirow[t]{2}{*}{ Parameters } & \multicolumn{3}{|l|}{ Groups } \\
\hline & $\begin{array}{l}\text { Non-pregnant } \\
\text { women } \\
(n=42)\end{array}$ & $\begin{array}{l}\text { Pregnant } \\
\text { women with } \\
\text { normal levels } \\
\text { of DHEAS } \\
<1.8(n=66)\end{array}$ & $\begin{array}{l}\text { Pregnant } \\
\text { women with } \\
\text { elevated } \\
\text { levels of } \\
\text { DHEAS >1.8 } \\
(n=44)\end{array}$ \\
\hline Age & $27.2 \pm 0.2$ & $26.1 \pm 0.1$ & $26.9 \pm 0.1$ \\
\hline Age at menarche & $13.2 \pm 0.1$ & $13.1 \pm 0.1$ & $14.3 \pm 0.1$ \\
\hline $\begin{array}{l}\text { Spontaneous } \\
\text { abortion }\end{array}$ & 0 & 0 & $16 \%$ \\
\hline Gestation period & - & $14.2 \pm 0.2$ & $15.1 \pm 0.1$ \\
\hline \multirow[t]{2}{*}{ DHEAS ( $\mu \mathrm{g} / \mathrm{ml})$} & $0.58 \pm 0.03$ & $0.61 \pm 0.04$ & $4.3 \pm 0.23$ \\
\hline & $0.2-1.8$ & $0.5-1.8$ & $2.0-11.2$ \\
\hline $\begin{array}{l}\text { Testosterone } \\
(\mathrm{nmol} / \mathrm{l})\end{array}$ & $0.45-3.75$ & $0.9-5.4$ & $1.0-7.3$ \\
\hline \multicolumn{4}{|l|}{ Clinical signs of } \\
\hline - hyperandrogenism & 0 & 0 & $86 \%$ \\
\hline $\begin{array}{l}\text { - menstrual } \\
\text { irregularities }\end{array}$ & 0 & 0 & $50 \%$ \\
\hline \multicolumn{4}{|l|}{$\begin{array}{l}\text { - hair growth in } \\
\text { androgen- }\end{array}$} \\
\hline Dependent areas & 0 & 0 & $43 \%$ \\
\hline - acne & 0 & 0 & $64 \%$ \\
\hline - oily seborrhea & 0 & 0 & $38 \%$ \\
\hline
\end{tabular}

with elevated levels of DHEAS ( $>1.8 \mathrm{mg} / \mathrm{ml}$ ) that could be attributed to minor forms of adrenal hyperandrogenia and were not associated with polycystic ovaries. All pregnant women were under 22 weeks of gestation. The groups of pregnant women were comparable in age $(26.1 \pm 0.1$ and $26.9 \pm 0.1$ years, respectively) and gestation period (14.2 \pm 0.2 and $15.1 \pm 0.1$ weeks, respectively). All patients participating in this study had no acute exacerbations of chronic diseases, acute infections, or other endocrine disorders. All individuals provided written informed consent to participate in this study that was approved by the local ethical committee of the Institute of Fundamental and Clinical Immunology.

\section{Generation of DCs}

Peripheral blood mononuclear cells (MNCs) were obtained by density gradient centrifugation (Ficoll-Paque, Sigma-Aldrich) of heparinized whole blood samples. DCs were generated by culturing the plastic-adherent MNC fraction in 6-well plates (Nunclon, Denmark) in RPMI-1640 medium (Sigma-Aldrich) supplemented with $0.3 \mathrm{mg} / \mathrm{ml} \mathrm{L}$-glutamine, $5 \mathrm{mM}$ HEPES buffer, $100 \mu \mathrm{g} / \mathrm{ml}$ gentamicin, and $5 \%$ fetal calf serum (FCS, Sigma-Aldrich) in the presence of recombinant human GM-CSF (40 ng/ $\mathrm{ml}$, Sigma-Aldrich) and rIFN- $\alpha$ (Roferon-A, $1000 \mathrm{U} / \mathrm{ml}$, Roche, Switzerland) for 4 days at $37^{\circ} \mathrm{C}$ in a $5 \% \mathrm{CO}_{2}$ 
atmosphere (IFN $\alpha$-DCs). The resulting DCs were then stimulated with $10 \mu \mathrm{g} / \mathrm{ml}$ lipopolysaccharide (LPS E. coli 0114: B4, Sigma-Aldrich) as a maturation stimulus for an additional $24 \mathrm{~h}$. In some experiments, DHEAS (Sigma-Aldrich, $10^{-6} \mathrm{M}$ ) was added to the DC culture along with LPS. The viability of IFN-DCs, as determined by Trypan blue exclusion, was at least $93-95 \%$ in all cases.

\section{Flow cytometric analysis}

Flow cytometry was performed using FACS Calibur and CellQuest software (BD Becton Dickinson). DC phenotypes were determined following direct single- or twocolor staining with FITC-, PE- or PerCP-conjugated mAb specific for CD83, CD25, HLA-DR, CD14, or B7-H1 (BD PharMingen). In each experiment, isotype-matched control mAbs were included to measure non-specific background staining.

\section{Analysis of intracellular expression and production of cytokines}

The capacity of DCs to activate $\mathrm{T}$ cell cytokine production was tested in allogeneic mixed lymphocyte cultures (MLCs). Freshly isolated monocyte-depleted allogeneic MNCs $\left(1 \times 10^{5}\right.$ per well) were cultured in complete culture medium supplemented with $10 \%$ FCS with or without DCs $\left(1 \times 10^{4}\right.$ per well $)$ in 96 -well plates for $72 \mathrm{~h}$. For the last 18 $\mathrm{h}$ of culture, $10 \mu \mathrm{g} / \mathrm{ml}$ Brefeldin A (Sigma-Aldrich) was added. Cells were harvested, washed, and incubated with APC-conjugated anti-CD3 mAb (BD Pharmingen) at room temperature for $15 \mathrm{~min}$. Cells were then permeabilized with $0.2 \%$ Tween-20 (Sigma-Aldrich), stained with FITClabeled anti-IFN- $\gamma$ or PE-labeled anti-IL-4 mAb (BD Pharmingen), and analyzed by flow cytometry.

To measure IFN- $\gamma$ and IL-4 secretion by T cells, after 5 days supernatants of co-cultured MNCs and allogenic IFN-DCs (at a MNC-to-DC ratio of 10:1) were collected and assayed using IFN- $\gamma$ and IL-4 ELISA kits according to the manufacturer's instructions (Vector-Best, Russia).

\section{Analysis of apoptosis}

To analyze the apoptosis of $\mathrm{CD}^{+} \mathrm{CD}^{+}{ }^{+}$and $\mathrm{CD} 3^{+} \mathrm{CD} 8^{+}$ $\mathrm{T}$ cells, IFN-DCs were co-cultured with $1 \times 10^{5}$ allogenic MNCs from healthy donors in 96-well round-bottom plates at a DC-to-MNC ratio of 1:10. After 3 days of incubation, cells were harvested, washed, and incubated with APC-conjugated anti-CD3 and PerCP-conjugated anti-CD4 Abs (BD Pharmingen) at room temperature for $15 \mathrm{~min}$. The percentage of apoptotic cells was determined using a FITC-conjugated Annexin V Apoptosis Detection Kit I according to the manufacturer's recommendations (BD Pharmingen). Apoptotic cells were identified by the binding of FITC-conjugated Annexin V and PI within the $\mathrm{CD}^{+} \mathrm{CD}^{+}$or $\mathrm{CD}^{+} \mathrm{CD}^{+}\left(\mathrm{CD}^{-}\right)$gates. Data were expressed as the percentage of positive cells among total
$\mathrm{CD}^{+}{ }^{+} \mathrm{CD} 4^{+}$and $\mathrm{CD}^{+} \mathrm{CD}^{+}{ }^{+} \mathrm{T}$ cells. At least 10,000 events were gathered from each sample.

\section{Statistical analysis}

Statistical analysis was performed using Statistica 6.0 software for Windows (StatSoft Inc.). Data were expressed as means \pm SE. The nonparametric Mann-Whitney U test was used to determine statistically significant differences. A threshold for significance of $\mathrm{p}<0.05$ was used.

\section{Results}

Because the functional activity of DCs largely depends on their maturity, we compared surface marker expression of DCs generated in normal pregnant women (NP-DCs) and pregnant women with hyperandrogenia (HA-DCs). DCs of non-pregnant fertile women were used as a control (control DCs). As shown in Figure 1, a two-fold lower percentage of $\mathrm{CD} 3^{+}$cells (a marker of mature monocytederived DCs) and $\mathrm{CD} 25^{+}$cells (a marker of activated mature DCs) were generated from normal pregnant women than from non-pregnant controls $\left(\mathrm{p}_{U}<0.01\right)$. Meanwhile, HA-DCs were not found to have a reduced percentage of $\mathrm{CD}_{3}{ }^{+}$and $\mathrm{CD}_{25}{ }^{+}$cells as compared to control DCs. Accordingly, the rate of $\mathrm{CD} 83^{+}$and $\mathrm{CD} 25^{+}$cells in the HA-DC population was two-fold higher than in NP-DCs. The percentage of $\mathrm{CD}_{14}{ }^{+}$cells (a monocyte/macrophage marker) in HA-DC cultures was also significantly higher than in NP-DCs. To explain the cause of the simultaneous increase in $\mathrm{CD} 83^{+}$and $\mathrm{CD} 14^{+}$cells, we characterized the co-expression of these molecules by DCs. In cultures of NP-DCs, about half of $\mathrm{CD}^{+} 3^{+}$cells coexpressed $\mathrm{CD} 14(4.3 \% \pm 0.9 \%)$ on their surface. The proportion of $\mathrm{CD}_{14} 4^{+} \mathrm{CD} 83^{+}$cells in HA-DCs was three times higher than that of women with a normal pregnancy (up to $14.0 \% \pm 2.5 \%, \mathrm{p}_{\mathrm{U}}<0.01$ ), and this explained the observed simultaneous increase in both $\mathrm{CD} 14^{+}$and $\mathrm{CD} 3^{+}$cells in the HA-DC populations.

To assess whether the impaired maturation/activation state of DCs could affect their functional activity, we further investigated the ability of DCs to stimulate $\mathrm{T}$ cell production of IFN- $\gamma$ and IL-4 in a MLC. DCs from nonpregnant controls (Table 2) stimulated a five-fold increase in the number of $\mathrm{CD}^{+}{ }^{+} \mathrm{IFN}-\gamma^{+} \mathrm{T}$ cells, but negligibly influenced the number of $\mathrm{CD}^{+}{ }^{+} \mathrm{IL}-4^{+} \mathrm{T}$ cells. Similar data were also obtained from an analysis of IFN- $\gamma$ and IL-4 secretion. The concentration of IFN- $\gamma$ in the supernatant of MLC, stimulated by DCs from non-pregnant women, was significantly higher than that in cultures without DCs. However, DCs did not significantly stimulate IL-4 secretion.

Compared to control DCs, NP-DCs did not induce an increased number of $\mathrm{CD}^{+} \mathrm{IFN}-\gamma^{+} \mathrm{T}$ cells and stimulated less secretion of IFN- $\gamma$, but did induce almost a three-fold increase in $\mathrm{CD}^{+} \mathrm{IL}_{-} 4^{+} \mathrm{T}$ cells and moderately enhanced 


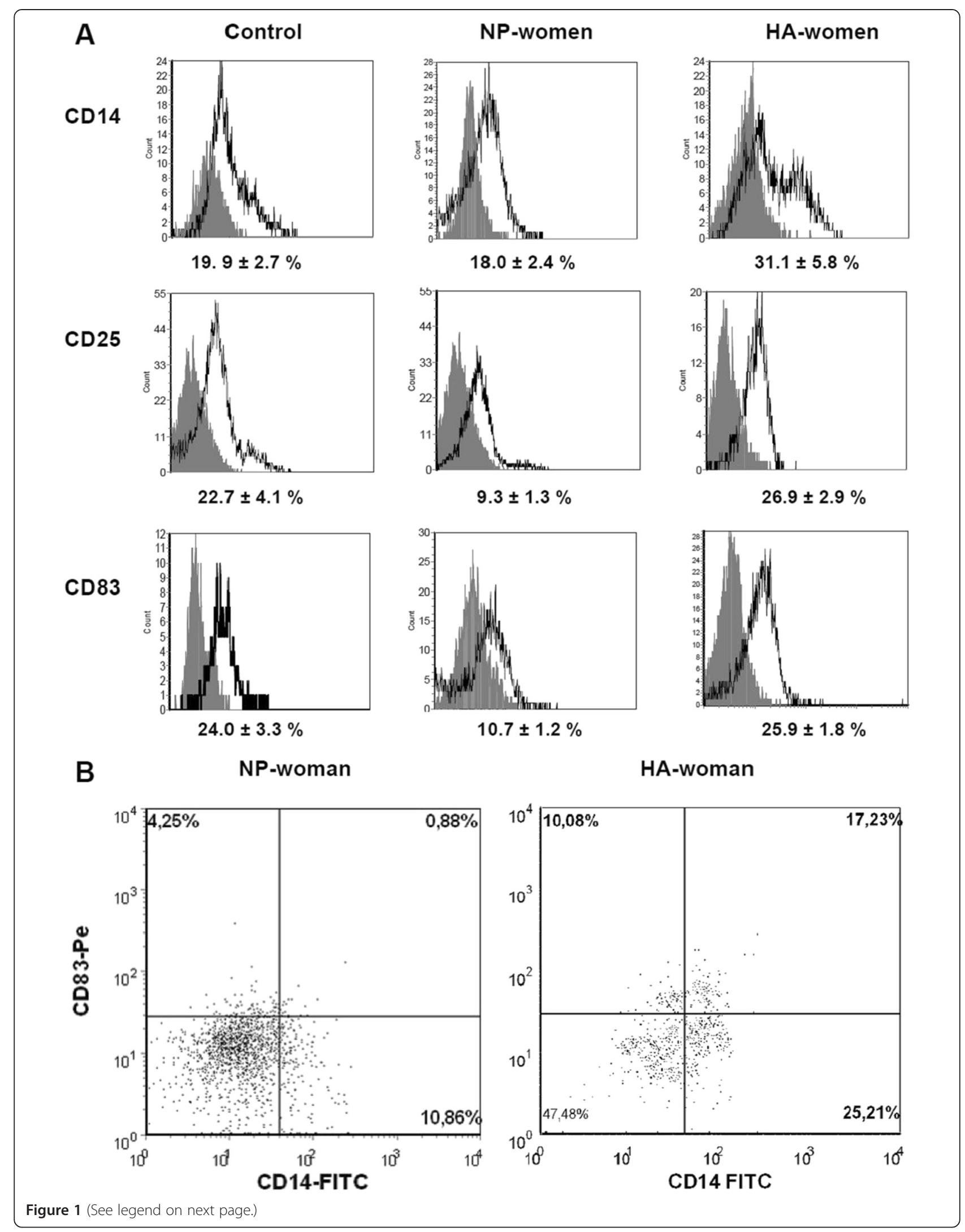


(See figure on previous page.)

Figure 1 Phenotypic characteristics of IFN- $a-D C s$ in normal pregnant women and pregnant women with hyperandrogenia. IFN-a-DCs were analyzed by flow cytometry for the expression of DC-related surface antigens in non-pregnant reproductive aged women (control group), normal pregnant women (NP-women), and pregnant women with hyperandrogenia (HA-women). (A) Histograms represent the expression of the indicated molecules (bold-line histograms) and the corresponding isotype controls (grey-filled histograms) in individual experiments. The relative percentage of positive cells (\%) among the DCs are presented as means ( \pm SE). (B) Gated HLA-DR IFN-a-DCs were analyzed for CD14 and CD83 staining. Representative stainings of IFN-a-DCs from NP-women (left, dot plots) and HA-women (right, dot plots) are shown.

IL-4 production. HA-DCs also stimulated the increase in $\mathrm{CD}^{+} \mathrm{IFN}-\gamma^{+} \mathrm{T}$ cells and secretion of IFN- $\gamma$, although their stimulatory effect was significantly lower than that of control DCs. Additionally, HA-DCs retained the ability to stimulate T2-responses, in particular to induce $\mathrm{CD} 3^{+} \mathrm{IL}-4^{+}$ T cells and increase IL-4 secretion.

To clarify whether the enhanced capacity of HA-DCs to stimulate IFN- $\gamma$ production by $\mathrm{T}$ cells could be attributed to increased level of DHEAS, we studied the direct effects of the hormone on the T1-stimulated activity of NP-DCs. Treatment of NP-DCs with DHEAS induced pronounced Th1-stimulatory activity. Levels of IFN- $\gamma$ in MLCs induced by DHEAS-modified NP-DCs were more than two-fold higher than that in the MLC, which were induced by intact NP-DCs $(344 \pm 160$ vs. $144 \pm 90 \mathrm{pg} / \mathrm{ml}$; $\left.\mathrm{P}_{\mathrm{U}}<0.05\right)$. Therefore, our findings suggest that DHEAS in vitro has a pronounced up-regulating effect on Th1stimulating capacity of NP-DCs.

Notably, DC tolerogenic activity might be associated with both the induction of Th2-responses and the ability of $\mathrm{T}$ cells to promote the apoptosis/anergy of cytotoxic $\mathrm{T}$ cells. Indeed, we recently found that donor IFN- $\alpha-D C s$ can induce $\mathrm{T}$ cell apoptosis via the PD-1/PD-L1 pathway, and enhanced expression of PD-L1 (B7-H1) on DCs could significantly increase their pro-apoptogenic activity in immunopathology [36,37]. Therefore, we compared the expression of B7-H1 and assessed DC cytotoxic activity in normal pregnant women and pregnant women with HA.

The percentage of $\mathrm{B} 7-\mathrm{H}^{+}$cells in the HLA-DR ${ }^{+}$subset of control DCs (Figure 2) varied from $20 \%$ to $54 \%$, and the average was $37.3 \% \pm 3.4 \%$. In normal pregnancy, the number of $\mathrm{B} 7-\mathrm{H} 1^{+} \mathrm{DCs}$ was significantly higher and reached an average of $85 \% \pm 2.6 \%$. The number of $\mathrm{B}^{-}-\mathrm{H1}^{+}$cells in HA-DC cultures was significantly lower than in NP-DC cultures $\left(73.7 \% \pm 2.7 \%\right.$ vs. $\left.85 \% \pm 2.6 \%, \mathrm{p}_{U}=0.027\right)$. Representative histograms of DC expression of HLA-DR and B7-H1 in women with a normal pregnancy or a pregnancy with HA are shown in Figure 3.

To analyze DC cytotoxic activity of NP-DCs and HADCs, we studied the amount of $\mathrm{CD} 4^{+}$and $\mathrm{CD} 8^{+} \mathrm{T}$-cell apoptosis in MLC that was induced by these DCs (Table 3 and Figure 4). NP-DCs and HA-DCs had similar proapoptogenic activity against $\mathrm{CD} 3^{+} \mathrm{CD} 4^{+} \mathrm{T}$ cells. The number of apoptotic (Annexin $\mathrm{V}^{+} / \mathrm{PI}^{-}$) $\mathrm{CD}^{+} \mathrm{CD}^{+} \mathrm{T}$ cells in MLC that were induced by DCs from pregnant women in both groups significantly exceeded the number of apoptotic cells in the controls (monocyte-depleted MNC cultures without DCs), but did not differ from each other. However, the percentage of apoptotic (Annexin $\mathrm{V}^{+} / \mathrm{PI}^{-}$) $\mathrm{CD}^{+} \mathrm{CD}^{+} \mathrm{T}$ cells in MLC that were induced by NP-DCs

Table 2 T1/T2-stimulatory activity of IFN-a-DCs

\begin{tabular}{|c|c|c|c|c|c|c|c|}
\hline & \multirow[t]{3}{*}{ Culture conditions } & \multicolumn{6}{|c|}{ Intracellular expression and production of the cytokines IFN- $\gamma$ and IL-4 } \\
\hline & & \multicolumn{2}{|c|}{ Control group $(n=10)$} & \multicolumn{2}{|c|}{ NP women $(n=8)$} & \multicolumn{2}{|c|}{ HA women $(n=8)$} \\
\hline & & Value & SI & Value & SI & Value & SI \\
\hline \multirow[t]{2}{*}{$\mathrm{CD}^{+} \mathrm{IFN}^{+} \gamma^{+}(\%)$} & 0 & $1.5 \pm 0.2$ & & $1.8 \pm 0.5$ & & $1.8 \pm 0.5$ & \\
\hline & $+\mathrm{DCs}$ & $5.9 \pm 0.6$ & $5.2 \pm 0.9$ & $1.5 \pm 0.27^{* *}$ & $1.1 \pm 0.2^{* *}$ & $2.5 \pm 0.3^{* * \#}$ & $2.0 \pm 0.4^{* * \#}$ \\
\hline \multirow[t]{2}{*}{$\mathrm{CD}^{+} \mathrm{IL}^{-} 4^{+}(\%)$} & 0 & $1.7 \pm 0.1$ & & $2.6 \pm 0.4$ & & $3.3 \pm 0.5$ & \\
\hline & $+\mathrm{DCs}$ & $2.1 \pm 0.4$ & $1.3 \pm 0.2$ & $8.6 \pm 1.0^{* *}$ & $3.5 \pm 0.4^{* *}$ & $7.4 \pm 1.0^{* *}$ & $2.4 \pm 0.5^{*}$ \\
\hline \multirow[t]{2}{*}{ IFN- $\gamma(p g / m l)$} & 0 & $18.2 \pm 5.7$ & & $16.5 \pm 2.8$ & & $16 \pm 3.0$ & \\
\hline & $+\mathrm{DCs}$ & $353 \pm 41$ & $22.2 \pm 3.1$ & $63.4 \pm 27.8^{* *}$ & $3.4 \pm 0.9^{* *}$ & $218 \pm 69^{*}$ \# & $13.5 \pm 3.1^{* \#}$ \\
\hline \multirow[t]{2}{*}{ IL-4 (pg/ml) } & 0 & $1.0 \pm 0.08$ & & $1.0 \pm 0.09$ & & $1.0 \pm 0.12$ & \\
\hline & $+D C s$ & $2.0 \pm 1.0$ & $2.0 \pm 1.0$ & $4.6 \pm 2.2$ & $4.6 \pm 2.2$ & $5.4 \pm 2.0^{*}$ & $5.4 \pm 2.0^{*}$ \\
\hline
\end{tabular}

Donor MNCs were co-cultured with allogenic IFN-a-DCs from non-pregnant women (control), normal pregnant women (NP), or hyperandrogenia pregnant women (HA) for $72 \mathrm{~h}$ at an MNC-to-DC ratio of 10:1. For the final $18 \mathrm{~h}$ of culture, $10 \mu \mathrm{g} / \mathrm{ml}$ Brefeldin A was added. Intracellular expression of IFN- $\gamma$ and IL-4 was detected within the $\mathrm{CD}^{+}$gate by flow cytometry. To determine the levels of cytokine production by MNCs, cell-free supernatants were collected after 5 days of co-culturing donor MNCs and allogenic IFN-a-DCs from the control group, NP-women, or HA-women (at a MNC-to-DC ratio of 10:1) and were assessed for production of IL-4 and IFN- $\gamma$ using specific ELISA kits. Data are presented as mean ( \pm SE) cytokine concentrations (pg/ml) or the percentage of CD $3^{+}$cells from the indicated number of independent experiments. SI indicates the stimulation index, which was calculated as the ratio of cytokine concentrations (pg/ml) or intracellular cytokine expression (\%) by MNCs in the presence or absence of DCs. ${ }^{*}, p_{U}<0.05,{ }^{* *}, p_{U}<0.01$, compared to the control women group; ${ }^{\#}$, $p_{U}<0.05$, compared to the NP-women group. Significant differences were detected using the Mann-Whitney $\mathrm{U}$ test. 

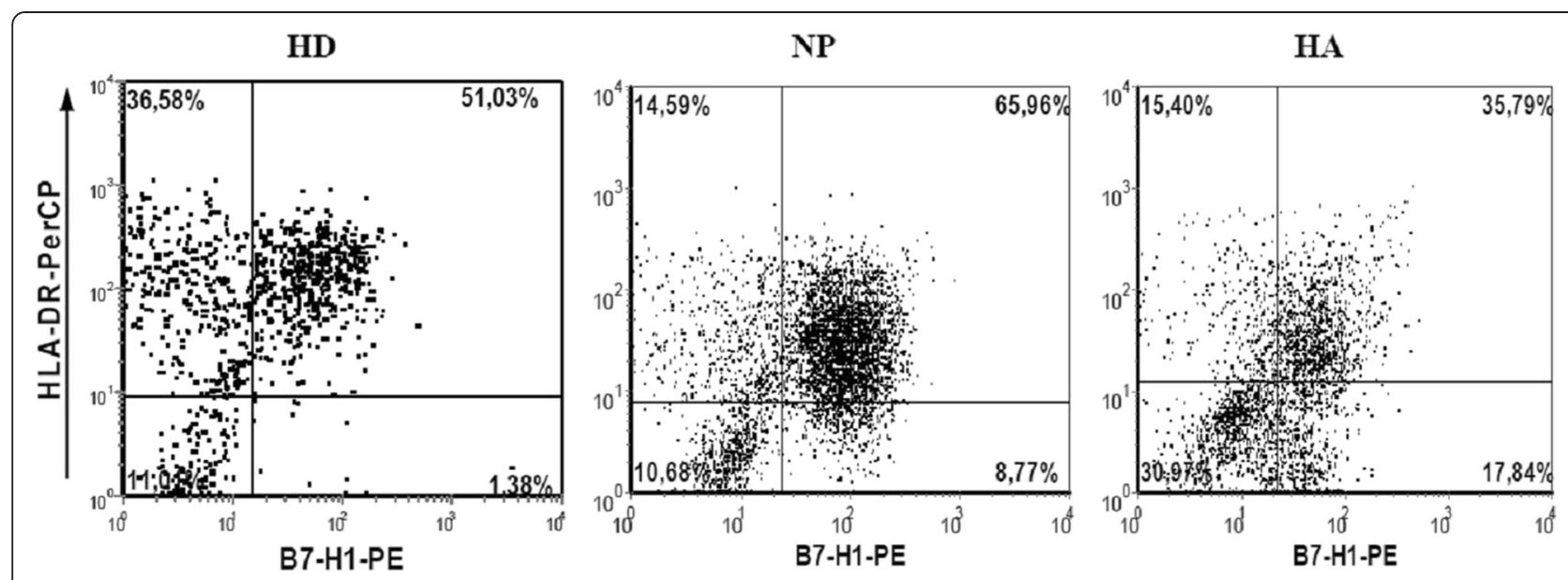

Figure 2 Expression of B7-H1 molecules by IFN-a-DCs from healthy donors (HD), normal pregnant (NP) women, and pregnant women with hyperandrogenia (HA). Data are presented as means ( \pm SE) percentage of cells positive for B7-H1 staining among all IFN-a-DCs expressing HLA-DR. *, $p_{U}<0.05$ indicates a significant difference compared to healthy donors $(n=12)$; $\#, p_{u}<0.05$ indicates a significant difference between groups of NP-women $(n=6)$ and HA-women $(n=8)$; comparisons were made using the Mann-Whitney $U$ test.

was significantly higher compared to MLC that were induced by HA-DCs.

\section{Discussion}

DCs represent unique antigen-presenting cells that are capable of inducing both an immune response and a state of immunological tolerance [10]. The presence of DCs in the decidua, where direct interactions between fetal and maternal cells occurs, makes these cells candidates to be key regulators of immune tolerance in pregnancy $[38,39]$. Nevertheless, DCs in human pregnancy are not well studied and findings are often contradictory.

In this paper, we demonstrated for the first time that DHEAS, whether elevated during pregnancy in vivo or added in vitro, results in the induction of DC maturation and type $1 \mathrm{~T}$ cell stimulatory activity and reduces the

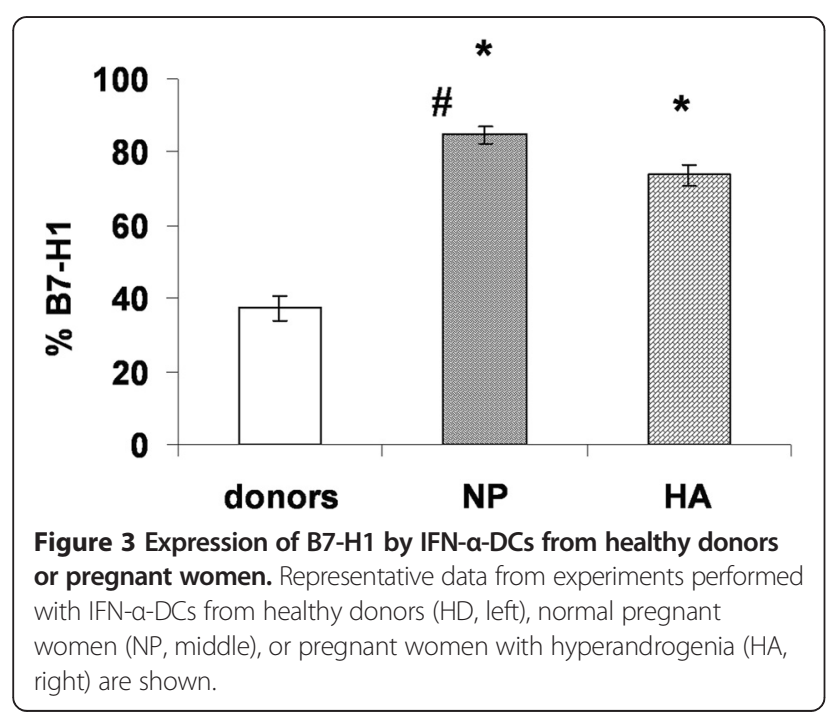

apoptosis-inducing activity of monocyte-derived DCs. Monocytes represent a major source of DC precursors and can differentiate into DCs upon exposure to GM-CSF in combination with IL-4 (IL-4-DCs) or IFN- $\alpha$ (IFN- $\alpha$ DCs) $[40,41]$. Because DHEAS has been reported to inhibit the secretion of IL-4 [42], we chose a DC generation protocol using GM-CSF and IFN- $\alpha$. The choice of this protocol was also motivated by the fact that unlike the IL-4-DCs that predominantly activate Th1-responses, IFN- $\alpha-D C s$ can activate both Th1- and Th2-responses [43,44] and possess more pronounced cytotoxic activity [45]. These attributes provide the opportunity to assess the effects of DHEAS on the Th1- and Th2-stimulating activity and cytotoxic effects of DCs.

Our data have shown that in a healthy pregnancy, monocyte-derived IFN- $\alpha$-DCs possess "tolerogenic" potential, as evidenced by a less mature phenotype and increased priming of type 2 (IL-4) T cell responses compared to DCs from non-pregnant women. Whereas DCs from non-pregnant women induce activated $\mathrm{T}$ cell production of IFN- $\gamma$, DCs from women with a normal pregnancy predominantly stimulated the production of IL-4. Our data are consistent with the findings of other groups, which demonstrate that the immature phenotype of myeloid DCs, reduced expression of co-stimulatory molecules (CD86 and CD80), and the expression of immunoglobulinlike transcript 3 (ILT-3) were involved in the induction of tolerance and the higher T2-stimulatory activity of decidual DCs in healthy pregnant women [46-48]. Regarding the properties of circulating DCs, Della Bella et al. showed that despite the higher expression of co-stimulatory molecules and the secretion of pro-inflammatory and regulatory cytokines, DCs in a healthy pregnancy were characterized by a low HLA-DR expression, which indicates the "incomplete" 
Table 3 IFN- $a-D C$ induced apoptosis of $\mathrm{CD}^{+} \mathrm{CD}^{+}$and $\mathrm{CD}^{+} \mathrm{CDB}^{+} \mathrm{T}$ cells

\begin{tabular}{llll}
\hline $\begin{array}{l}\text { Annexin } \\
\mathbf{V}^{+} / \mathrm{PI}^{-}(\%)\end{array}$ & $\begin{array}{l}\text { Untreated MNCs, } \\
\mathbf{n}=\mathbf{8}\end{array}$ & $\begin{array}{l}\text { MNCs + DCs } \\
(\mathbf{N P}), \mathbf{n}=\mathbf{6}\end{array}$ & $\begin{array}{l}\text { MNCs + DCs } \\
(\mathbf{H A}), \mathbf{n}=\mathbf{8}\end{array}$ \\
\hline $\mathrm{CD}^{+} \mathrm{CD}^{+}$ & $0.19 \pm 0.05$ & $4.7 \pm 1.0^{*}$ & $5.3 \pm 1.2^{*}$ \\
$\mathrm{~T}$ cells & 0.25 & 3.6 & 3.92 \\
$\mathrm{CD}^{+} \mathrm{CD}^{+}$ & $0.17 \pm 0.04$ & $15.02 \pm 0.3^{*}$ & $11.19 \pm 0.9^{* \#}$ \\
T cells & 0.13 & 15.0 & 11.23 \\
\hline
\end{tabular}

Untreated MNCs from healthy donors (control) and MNCs co-cultured with IFNa-DCs from normal pregnant (NP) women or pregnant women with hyperandrogenia (HA) at a MNC-to-DC ratio of 10:1 for 3 days were analyzed for Annexin V/PI double positivity by flow cytometry. Data are presented as mean $( \pm \mathrm{SE})$ percentages and medians of apoptotic Annexin $\mathrm{V}^{+} / \mathrm{PI}^{-}$cells within the $\mathrm{CD3}^{+} \mathrm{CD}^{+}$or $\mathrm{CD}_{3}{ }^{+} \mathrm{CD}^{+}\left(\mathrm{CD}^{-}\right)$gates. ${ }^{*}$, $\mathrm{p}_{\mathrm{u}}<0.05$, compared to the control group; ${ }^{\#}, \mathrm{p}_{U}<0.01$, a significant difference between the NP pregnant women and $\mathrm{HA}$ pregnant women groups; differences were detected using the Mann-Whitney U test.

activation of these DCs. Moreover, when blood serum from pregnant women was added to control DCs, it induced a DC phenotype associated with low allo-stimulatory activity [49]. For monocyte-derived DCs, Bachy et al. showed that DCs generated by culturing cells from a normal pregnancy in the presence of GM-CSF and IL-4 were phenotypically less mature and characterized by reduced IL-12 and increased IL-10 secretion [50]. However, these authors did not investigate the capacity of these DCs to activate T1 and T2 immune responses.

The second important finding of this study is that DCs from women with elevated levels of DHEAS exhibit no signs of immaturity and, along with a capacity to stimulate the T cell secretion of IL-4, can also activate the production of IFN- $\gamma$. Because DHEAS, when added to DCs derived from women with a normal pregnancy, induced T1-stimulatory activity, we suggest that the capacity of
HA-DCs to prime type $1 \mathrm{~T}$ cell responses in pregnant women with HA could be explained by the elevated levels of this hormone.

Another interesting aspect of this study is our analysis of DC cytotoxic activity. Previously, we showed that IFN$\alpha$-DCs from healthy donors can induce the apoptosis of activated NK cells, and the maturation of IFN- $\alpha-D C s$ upon exposure to DHEAS is associated with the downregulation of cytotoxic activity [51]. Furthermore, we showed that IFN- $\alpha$-DCs could induce T cell apoptosis, which is largely mediated through the PD-L1 (B7-H1)/ PD-1 signaling pathway [47]. As B7-H1 expression on IFN- $\alpha$-DCs declines along with DC maturation [52], we suggest that DC maturation induced by DHEAS could decrease DC cytotoxic potential against $\mathrm{T}$ cells. Indeed, our study showed that in a normal pregnancy DCs were characterized by increased expression of B7-H1 compared to control DCs. Furthermore, in pregnant women with elevated levels of DHEAS, the number of $\mathrm{B} 7-\mathrm{H} 1^{+}$DCs was significantly lower than in a normal pregnancy. Moreover, the reduced expression of $\mathrm{B} 7-\mathrm{H} 1$ was associated with lower $\mathrm{DC}$ cytotoxicity against $\mathrm{CD} 3^{+} \mathrm{CD} 8^{+} \mathrm{T}$ cells. Overall, these findings suggest that in pregnant women with elevated levels of DHEAS, the tolerogenic properties of DCs were significantly reduced, which could contribute to impaired "immunosuppressive" re-arrangements of the immune system in HA.

The reduced tolerogenic potential of DCs has been proposed as one of the causative factors of abnormal pregnancy in recurrent pregnancy loss [39] and pre-eclampsia [53]. However, impaired DC functions in pregnant women with increased levels of DHEAS are described herein for the first time. Our findings shed new light on immune-

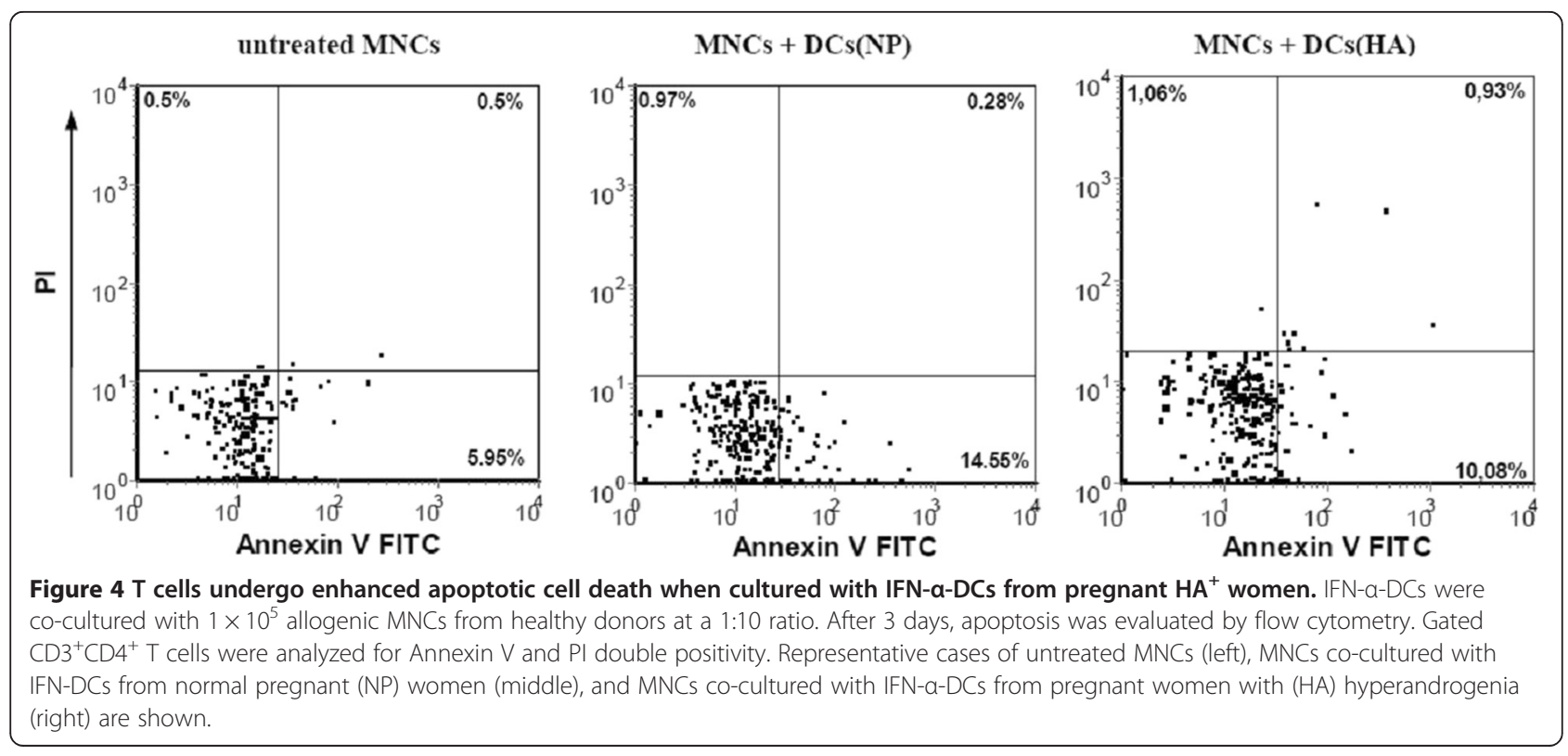


endocrine interactions and their importance in normal and complicated pregnancies.

\section{Conclusions}

We report that in healthy pregnancy IFN- $\alpha$-induced monocyte-derived DCs are characterized by the immature phenotype, the potent ability to stimulate type $2 \mathrm{~T}$ cell responses and to induce $\mathrm{T}$ cell apoptosis. In contrast, DCs from pregnant women with hyperandrogenia have a mature phenotype, are able to stimulate both type 1 (IFN- $\gamma$ ) and type 2 (IL-4) T cell responses, and differ by lower apoptosis-inducing activity. In addition, DHEAS, when added in vitro to DCs from healthy pregnants, induces the maturation of DCs and increases their ability to activate type $1 \mathrm{~T}$ cell responses. This indicates a reduced tolerogenic potential of DCs from pregnant women with HA and reveals a new mechanism involved in the hormonal regulation of DCs mediated by DHEAS.

\section{Competing interests}

The authors declare that they have no competing interests.

\section{Authors' contributions}

EC and OL were the principal investigators and take primary responsibility for the paper; NS and NK recruited patients; OL, MT, and TT performed laboratory work for this study; AO participated in the statistical analysis; NP coordinated the research; EC, OL, and $\Pi T$ wrote the manuscript. All authors read and approved the final manuscript.

\section{Acknowledgements}

This study was funded by the Russian Foundation for Basic Research (Number 0904 00525).

\section{Author details \\ ${ }^{1}$ Laboratory of Cellular Immunotherapy, Research Institute of Fundamental and Clinical Immunology, 14, Yadrintsevskaya St., 630099 Novosibirsk, Russia. ${ }^{2}$ Novosibirsk State University, 2, Pirogova St., 630090 Novosibirsk, Russia.}

Received: 4 September 2014 Accepted: 11 December 2014

Published online: 31 January 2015

\section{References}

1. Medawar PB. Some immunological and endocrinological problems raised by the evolution of viviparity in vertebrates. Symp Soc Exp Biol. 1953:44:320-38

2. Taglauer ES, Adams Waldorf KM, Petroff MG. The hidden maternal-fetal interface: events involving the lymphoid organs in maternal-fetal tolerance. Int J Dev Biol. 2010;54(2-3):421-30.

3. Guleria I, Sayegh MH. Maternal acceptance of the fetus: true human tolerance. J Immunol. 2007;178(6):3345-51.

4. James E, Chai JG, Dewchand H, Macchiarulo E, Dazzi F, Simpson E. Multiparity induces priming tomale-specific minor histocompatibility antigen, HY, in mice and humans. Blood. 2003;102:388-93.

5. Jiang SP, Vacchio MS. Multiple mechanisms of peripheral T cell tolerance to the fetal «allograft». J Immunol. 1998;160:3086-90.

6. Guerin LR, Prins JR, Robertson SA. Regulatory T-cells and immune tolerance in pregnancy: a new target for infertility treatment? Hum Reprod. 2009;15(5):517-35.

7. Kushwah $\mathrm{R}, \mathrm{Hu}$ J. Role of dendritic cells in the induction of regulatory T cells. Cell Biosci. 2011:1:1-20.

8. Raghupathy R. Pregnancy: success and failure within the Th1/Th2/Th3 paradigm. Semin Immunol. 2001;13:219-27.

9. Sykes L, Macintyre DA, Yap XJ, Teoh TG, Bennett PR: The Th1:Th2 dichotomy of pregnancy and preterm labour. Mediators Inflamm 2012, 967629. doi:10.1155/2012/967629
10. Banchereau J, Briere F, Caux C, Davoust J, Lebecque S, Liu YJ, et al. Immunobiology of dendritic cells. Annu Rev Immunol. 2000;18:767-811.

11. Adams S, O'Neill DW, Bhardwaj N. Recent advances in dendritic cell biology. J Clin Immunol. 2005:25:177-88.

12. Steinman RM, Hawiger D, Nussenzweig MC. Tolerogenic dendritic cells. Annu Rev Immunol. 2003;21:685-711.

13. Kuwana M, Kaburaki J, Wright TM, Kawakami Y, Ikeda Y. Induction of antigen-specific human $\mathrm{CD} 4\left(^{+}\right) \mathrm{T}$ cell anergy by peripheral blood DC2 precursors. Eur J Immunol. 2001;31:2547-57.

14. Lutz M: Therapeutic potential of semi-mature dendritic cells for tolerance induction. Front.Immunol. doi: 10.3389/fimmu.2012.00123

15. Rutella S, Danese S, Leone G. Tolerogenic dendritic cells: Cytokine modulation comes of age. Blood. 2006;108:1435-40.

16. Manicassamy S, Pulendran B. Dendritic cell control of tolerogenic responses. Immunol Rev. 2011;241(1):206-27.

17. Gregori S. Dendritic cells in networks of immunological tolerance. Tissue Antigens. 2010;77:89-99.

18. Hu J, Wan Y. Tolerogenic dendritic cells and their potential applications. Immunology. 2011;132(3):307-14.

19. Tagliani E, Erlebacher A. Dendritic cell function at the maternal-fetal interface. Expert Rev Clin Immunol. 2011;7(5):593-602.

20. Guo PF, Du MR, Wu HX, Lin Y, Jin LP, Li DJ. Thymic stromal lymphopoietin from trophoblasts induces dendritic cell-mediated regulatory $\mathrm{TH} 2$ bias in the decidua during early gestation in humans. Blood. 2010;116:2061-9.

21. Adams KM, Yan Z, Stevens AM, Nelson JL. The changing maternal «self» hypothesis: a mechanism for maternal tolerance of the fetus. Placenta. 2007;28:378-82.

22. Liang J, Sun L, Wang Q. Progesterone regulates mouse dendritic cells differentiation and maturation. Int Immunopharmacol. 2006;6:350-5.

23. Segerer SE, Meller N, van den Brandt J, Kapp M, Dietl J. Modulation of maturation and function of dendritic cells by female sex steroid hormones. Amer J Reprod Immunol. 2008;60:86-96.

24. Matasic R, Dietz AB, Vuk-Pavlovic S. Dexamethasone inhibits dendritic cell maturation by redirecting differentiation of a subset of cells. J Leukoc Biol. 1999;66(6):909-14.

25. Wan H, Versnel MA, Leijten LM, van Helden-Meeuwsen CG, Fekkes D. Modulation of maturation and function of dendritic cells by female sex steroid hormones Chorionic gonadotropin induces dendritic cells to express a tolerogenic phenotype. J Leukoc Biol. 2008;83(4):894-901.

26. Kovats S, Carreras E. Regulation of dendritic cell differentiation and function by estrogen receptor ligands. Cell Immunol. 2008;252:81-90.

27. Butts CL, Candando KM, Warfel J, Belyavskaya E, D'Agnillo F, Sternberg EM. Progesterone regulation of uterine dendritic cell function in rodents is dependent on the stage of estrous cycle. Mucosal Immunol. 2010;3(5):496-505.

28. Blois SM, Kammerer U, Alba Soto C, Tometten MC, Shaikly V, Barrientos G, et al. Dendritic cells: key to fetal tolerance? Biol Reprod. 2007;77:590-8

29. Seledtsova NV, Khonina NA, Dudareva AV, Tihonova MA, Ostanin AA, Pasman NM, et al. Characteristic of natural cytotoxic cells and regulatory T-lymphocytes in pregnant women with hyperandrogenia. Immunology. 2007;3:151-5 (in Russian).

30. Winger $\mathrm{EE}$, Reed JL. Low circulating $\mathrm{CD} 4^{+} \mathrm{CD} 25^{+} \mathrm{Foxp}^{+} \mathrm{T}$ regulatory cell levels predict miscarriage risk in newly pregnant women with a history of failure. Am J Reprod Immunol. 2011;66:320-8.

31. Shakhar K, Rosenne E, Loewenthal R, Shakhar G, Carp H, Ben-Eliyahu S. High NK cell activity in recurrent miscarriage: what are we really measuring? Hum Reprod. 2006;21(9):2421-5.

32. Moran C, Azziz R, Weintrob N, Witchel SF, Rohmer V, Dewailly D, et al. Reproductive outcome of women with 21-hydroxylase-deficient nonclassic adrenal hyperplasia. J Clin Endocrinol Metabolism. 2006;91(9):3451-6.

33. Gurbuz B, Yalti S, Fiçicioglu C, Ozden S, Yildirim G, Sayar C. Basal hormone levels in women with recurrent pregnancy loss. Gynecol Endocrinol. 2003;17(4):317-21.

34. Powell JM, Sonnenfeld G. The effects of Dehydroepiandrosterone (DHEA) on in vitro spleen cell proliferation and cytokine production. J Interferon Cytokine Res. 2006;26(1):34-9.

35. Seledtsova NV, Khonina NA, Tikhonova MA, Ostanin AA, Pasman NM, Chernykh ER. Effect of dehydroepiandrosterone sulfate on the phenotype and functions of dendritic cells in vitro. Med Immunol. 2007:9(6):589-96 (in Russian).

36. Tyrinova TV, Leplina OY, Tikhonova MA, Sakhno LV, Ostanin AA, Chernykh ER. Characteristics of signaling pathways mediating a cytotoxic activity of 
dendritic cells upon activated T lymphocytes and NK cells. Med Immunol. 2012;14(1-2):43-50 (in Russian).

37. Sakhno LV, Tikhonova MA, Tyrinova TV, Leplina OY, Shevela EY at al: Cytotoxic Activity of Dendritic Cells as a Possible Mechanism of Negative Regulation of T Lymphocytes in Pulmonary Tuberculosis. Clinical and Developmental Immunology 2012, Article ID 628635, 9 doi:10.1155/2012/628635

38. Kammerer U, Kruse A, Barrientos G, Arck PC, Blois SM. Role of dendritic cells in the regulation of maternal immune responses to the fetus during mammalian gestation. Immunol Invest. 2008;37(5):499-533.

39. Askelund K, Liddell HS, Zanderigo AM, Fernando NS, Khong TY, Stone PR, et al. $\mathrm{CD}_{3}\left(^{+}\right)$dendritic cells in the decidua of women with recurrent miscarriage and normal pregnancy. Placenta. 2004;25:140-5.

40. Thurner B, Roder C, Dieckmann D, Heuer M, Kruse M, Glaser A, et al. Generation of large numbers of fully mature and stable dendritic cells from leukapheresis products for clinical applications. J Immunol Meth. 1999:223:1-15.

41. Santini S, Pucchini T, Lapenta C, Parlato S, Logozzi M, Belardelli F, et al. A new type 1 IFN-mediated pathway for the rapid differentiation of monocytes into highly active dendritic cells. Stem Cells. 2003;21:357-62.

42. Tabata N, Tagami H, Terui T. Dehydroepiandrosterone may be one of the regulators of cytokine production in atopic dermatitis. Arch Dermatol Res. 1997;289(7):410-4.

43. Santini S, Lapenta C, Logozzi M, Parlato S, Spada M, Pucchio T, et al. Type I Interferon as a powerful adjuvant for monocyte-derived dendritic cells development and activity in vitro and in HU-PBL-SCID mice. J Exp Med. 2000;191:1777-88.

44. Della Bella S, Nicola S, Riva A, Biasin M, Clerici M, Villa ML. Functional repertoire of dendritic cells generated in granulocyte macrophage-colony stimulating factor and interferon-a. J Leukocyte Biol. 2004;75:106-16.

45. Papewalis C, Jacobs B, Wuttke M, Ullrich E, Baehring T, Fenk R, et al. IFN-a skews monocytes into CD56 + -expressing dendritic cells with potent functional activities in vitro and in vivo. J Immunol. 2008;80(3):1462-70.

46. Gardner L, Moffett A. Dendritic cells in the human decidua. Biol Reprod. 2003:69:1438-46.

47. Ban YL, Kong BH, Qu X, Yang QF, Ma YY. BDCA-1+, BDCA-2+ and BDCA-3+ dendritic cells in early human pregnancy deciduas. Clin Exp Immunol. 2008;151:399-406.

48. Miyazaki S, Tsuda H, Sakai M, Hori S, Sasaki Y, Futatani T, et al. Predominance of Th2-promoting dendritic cells in early human pregnancy decidua. J Leukoc Biol. 2003;74:514-22.

49. Della Bella S, Giannelli S, Cozzi V, Signorelli V, Cappelletti M, et al. Incomplete activation of peripheral blood dendritic cells during healthy human pregnancy. Clin Exp Immunol. 2011;164(2):180-92.

50. Bachy V, Williams DJ, Ibrahim MA. Altered dendritic cell function in normal pregnancy. J Reprod Immunol. 2008;78(1):11-21.

51. Leplina O, Yu Tikhonova MA, Tyrinova TV, Alyamkina EA, Dolgova EV Bogachev SS, et al. Comparative characteristic of phenotype and cytokine-secretory activity of human dendritic cells generated in vitro with IFN-alpha and IL-4. Immunology. 2012;33(2):60-5. in Russian).

52. Seledtsova NV, Khonina NA, Tihonova MA, Pasman NM, Ostanin AA, Chernykh RR, et al. The interaction of NK-cells with dendritic cells modified by dehydroepiandrosterone sulfate. Immunology. 2008;2:80-4 (in Russian).

53. Huang SJ, Chen CP, Schatz F, Rahman M, Abrahams VM, Lockwood CJ. Pre-eclampsia is associated with dendritic cell recruitmnt into the uterine decidua. J Pathol. 2008;214:328-36.

\section{Submit your next manuscript to BioMed Central and take full advantage of:}

- Convenient online submission

- Thorough peer review

- No space constraints or color figure charges

- Immediate publication on acceptance

- Inclusion in PubMed, CAS, Scopus and Google Scholar

- Research which is freely available for redistribution 